\title{
High $\mathrm{K}^{+}$-Induced Relaxation by Nitric Oxide in Human Gastric Fundus
}

\author{
Dae Hoon Kim ${ }^{1, \ddagger}$, Young Chul Kim ${ }^{2, *}{ }^{,}$, Woong Choi ${ }^{3, \ddagger}$, Hyo-Young Yun ${ }^{1, \dagger, \ddagger}$, Rohyun Sung ${ }^{4}$, Hun Sik \\ $\mathrm{Kim}^{3}$, Heon Kim ${ }^{5}$, Ra Young Yoo ${ }^{2}$, Seon-Mee Park ${ }^{6}$, Sei Jin Yun ${ }^{6}$, Young-Jin Song ${ }^{1}$, Wen-Xie Xu ${ }^{7}$, and \\ Sang Jin Lee $^{2}$
}

Departments of ${ }^{1}$ Surgery, ${ }^{2}$ Physiology, ${ }^{3}$ Pharmacology, ${ }^{4}$ Pathology, ${ }^{5}$ Preventing Medicine and ${ }^{6}$ Internal Medicine, Chungbuk National University College of Medicine, Cheongju 361-763, Korea, ${ }^{7}$ Department of Physiology, College of Medcine, Shanghai Jiaotong University, Shanghai 200240, China

This study was designed to elucidate high $\mathrm{K}^{+}$-induced relaxation in the human gastric fundus. Circular smooth muscle from the human gastric fundus greater curvature showed stretch-dependent high $\mathrm{K}^{+}(50 \mathrm{mM})$-induced contractions. However, longitudinal smooth muscle produced stretch-dependent high $\mathrm{K}^{+}$-induced relaxation. We investigated several relaxation mechanisms to understand the reason for the discrepancy. Protein kinase inhibitors such as KT 5823 (1 $\mu$ M) and KT 5720 (1 $\mu$ M) which block protein kinases (PKG and PKA) had no effect on high $\mathrm{K}^{+}$-induced relaxation. $\mathrm{K}^{+}$channel blockers except 4-aminopyridine (4-AP), a voltage-dependent $K^{+}$channel $\left(K_{V}\right)$ blocker, did not affect high $\mathrm{K}^{+}$-induced relaxation. However, $\mathrm{N}(\mathrm{G})$-nitro-L-arginine and $1 \mathrm{H}-(1,2,4)$ oxadiazolo $(4,3-\mathrm{A})$ quinoxalin-1-one, an inhibitors of soluble guanylate cyclase (sGC) and 4-AP inhibited relaxation and reversed relaxation to contraction. High $\mathrm{K}^{+}$-induced relaxation of the human gastric fundus was observed only in the longitudinal muscles from the greater curvature. These data suggest that the longitudinal muscle of the human gastric fundus greater curvature produced high $\mathrm{K}^{+}$-induced relaxation that was activated by the nitric oxide/sGC pathway through a $K_{V}$ channel-dependent mechanism.

Key Words: Fundus, High $\mathrm{K}^{+}$, Human stomach, Longitudinal smooth muscle, Nitric oxide, Relaxation

\section{INTRODUCTION}

The stomach performs complex function such as storage of food, breaking up of food particles, and emptying of its contents at a controlled rate [1,2]. Ingested food is stored in the gastric fundus and then triturated into the antral region of the stomach. Liquids and chime are passed into the duodenum through sieving and decanting, whereas solid particles are retained for longer periods. How these complicating mechanisms and processes are coordinated is still incompletely understood, except for several reflexes [3]. To date, the gastric fundus has been known to accommodate

Received May 3, 2012, Revised August 9, 2012,

Accepted August 19, 2012

${ }^{*}$ Corresponding to: Young Chul Kim, Department of Physiology, Chungbuk National University College of Medicine, 52 Naesudongro, Heungduk-gu, Cheongju 361-763, Korea. (Tel) 82-43-261-2859, (Fax) 82-43-261-2859, (E-mail) physiokyc@chungbuk.ac.kr

+Co-correspondence to: Hyo-Young Yun, Department of Surgery, Chungbuk National University College of Medicine, 52 Naesudongro, Heungduk-gu, Cheongju 361-763, Korea. (Tel) 82-43-269-6032, (Fax) 82-43-266-6037, (E-mail) yunhyo@chungbuk.ac.kr

${ }^{*}$ These authors contributed equally to this work.

(i) (8) This is an Open Access article distributed under the terms of the Creative Commons Attribution Non-Commercial License (http: Creative Commons Attribution Non-Commercial License (http// creativecommons.organd reproduction in any medium, provided the original work food via a reflex called receptive relaxation [1,2,4]. This reflex is characterized by graded wall distension with a small increase in intragastric pressure [4,5]. As receptive relaxation has been reported only in the fundus, we evaluated each part of the stomach according to gastric muscle layer as well as gastric region to understand the exact location of this phenomenon.

A non-adrenergic non-cholinergic (NANC) inhibitory mechanism is the final effectors of gastric receptive relaxation in the gastric fundus [5]. Nitric oxide (NO), whose formation is catalyzed by nitric oxide synthase (NOS) from L-arginine, is an inhibitory neurotransmitter that mediates smooth muscle relaxation in the mammalian gastrointestinal (GI) tract [4]. Neurogenic relaxation of the gastric fundus depends on a combination of NO and vasoactive intestinal peptide release [6,7]. In addition, NO plays an important role in the relaxation process of the gastric fundus

ABBREVIATIONS: PK, protein kinase; sGC, an inhibitor of soluble guanylate cyclase; NANC, non-adrenergic noncholinergic; NO, nitric oxide; NOS, nitric oxide synthase; GI tract, gastrointestinal tract; $\mathrm{VDCC}_{\mathrm{L}}$, voltage-dependent L-type $\mathrm{Ca}^{2+}$ channels; GC, greater curvature; LC, lesser curvature; ACh, acetylcholine; SNP, sodium nitroprusside; TEA, tetraethylammonium; $\mathrm{K}_{\mathrm{ca}}$ channel, $\mathrm{Ca}^{2+}$-activated $\mathrm{K}^{+}$ chaanel; KBC, $\mathrm{K}^{+}$channel blockers cocktail; L-NNA, N(G)-nitroL-arginine; ODQ, 1H-(1,2,4)oxadiazolo (4,3-A)quinoxalin-1-one; 4-AP 4-aminopyridine; $\mathrm{K}_{\mathrm{V}}$ channel, voltage-dependent $\mathrm{K}^{+}$channel; $\mathrm{NBC}$, nerve blockers cocktail; $\left[\mathrm{Ca}^{2+}\right]_{\mathrm{i}}$, intracellular $\mathrm{Ca}^{2+}$; ICC, interstitial cells of Cajal. 
as reported in intact animals [8], and in isolated stomachs from guinea-pigs [4], mice [9], and humans [10]. To date, only a few studies have reported on the nature of neurogenic NANC relaxation in the human stomach.

Voltage dependent "L-type" $\mathrm{Ca}^{2+}$ channels $\left(\mathrm{VDCC}_{\mathrm{L}}\right)$ play a central role in the regulation of $\left[\mathrm{Ca}^{2+}\right]_{i}$ in smooth muscle [11]. $\mathrm{Ca}^{2+}$ is a key factor in the regulation of smooth muscle contraction [11]. Among various conditions, high $\mathrm{K}^{+}$stimulation produces contraction through membrane depolarization, which activates $\mathrm{VDCC}_{\mathrm{L}}$ in gastric smooth muscle [12]. This mechanism is true except for the longitudinal muscles of the fundus, where high $\mathrm{K}^{+}$produces relaxation [13]. We recently found high $\mathrm{K}^{+}$-induced relaxation of human corporal longitudinal smooth muscle is NO mediated. However, we could not evaluate the precise mechanisms of the opposed response to high $\mathrm{K}^{+}$stimulation such as the NO source in these muscles. In addition, we still have no information on whether the high $\mathrm{K}^{+}$-mediated response shows regional differences in the human stomach.

Thus, this study focused on the region of the stomach that shows high $\mathrm{K}^{+}$-mediated relaxation and the main mechanisms responsible for the relaxation effect.

\section{METHODS}

\section{Tissue preparation for isometric contraction}

Human gastric tissues from both greater and lesser curvature were obtained from patients who underwent total gastrectomy. Some tissue sample obtained by total gastrectomy who already underwent subtotal gastrectomy. This specific sample was obtained from patient underwent repetitive gastrectomy for recurrence of gastric cancer. All patients gave written informed consent and this experimental protocol for using human stomach was also approved by the Institutional Review Board for Clinical Research of Chungbuk National University. Specimens from macroscopically normal tissue of neoplastic area were removed immediately after surgical resection of stomach. In Krebs (KRB) solution, specimens were pinned down on sylgard plate. After removal of mucosa and submucosa, muscle strips $(0.5 \times 2 \mathrm{~cm}, 0.5 \mathrm{~cm}$ thickness $)$ were prepared from the fundus according to muscle direction (circular and longitudinal direction) and mounted to organ bath $(25 \mathrm{ml}$ and $75 \mathrm{ml}$ ) of isometric contractile measuring system. For confirmation pathologist identified smooth muscles of human stomach using HE staining later. In vertical chamber, one end of strip was tied tightly to the holder and the other side was linked to force transducer by hook type holder (Harvard, USA). Force transducer was connected to PowerLab-Data Acquisition System, which was linked to IBM compatible computer operated by Charter v5.5 software (ADinstruments, Colorado, USA) for measuring isometric contraction. Each strip was stretched passively to resting tension after $1 \sim 1.5$ hours equilibration. Then contractile responses of the strip to the high $\mathrm{K}^{+}(50 \mathrm{mM}, 10$ min) was repeated two or three times until the responses were reproducible.

\section{Solution and drugs}

KRB solution ( $\mathrm{CO}_{2} /$ bicarbonate-buffered Tyrode) contained (in $\mathrm{mM}$ ): $\mathrm{NaCl} 122, \mathrm{KCl} 4.7, \mathrm{MgCl}_{2} 1, \mathrm{CaCl}_{2} 2$, $\mathrm{NaHCO}_{3}$ 15, $\mathrm{KH}_{2} \mathrm{PO}_{4}$ 0.93, and glucose $11(\mathrm{pH} 7.3 \sim 7.4$, bubbled with $5 \% \mathrm{CO}_{2} / 95 \% \mathrm{O}_{2}$ ). Equimolar concentration of $\mathrm{Na}^{+}$was replaced by $\mathrm{K}^{+}$to make high $\mathrm{K}^{+}(50 \mathrm{mM})$ solution. The external solution was changed by solutions which had previously been incubated (bubbled with $5 \% \mathrm{CO}_{2} / 95 \% \mathrm{O}_{2}$, $36^{\circ} \mathrm{C}$ ) in water bath before the application. Sustained response by high $\mathrm{K}^{+}$stimulus in the presence and absence of various blockers in this study was recorded for $10 \mathrm{~min}$ and measured at end of recording at $10 \mathrm{~min}$. And pretreatment of various blockers was applied for 12 min before the application of high $\mathrm{K}^{+} . \mathrm{K}^{+}$channel blockers cocktail except 4-AP (KBC) was applied (tetraethylammonium, (TEA, 10 $\mathrm{mM}$ ); apamin (APA, $300 \mathrm{nM}$ ); glibenclamide (Glib, $20 \mu \mathrm{M}$ ); $\mathrm{Ba}^{2+}(1 \mathrm{mM})$ before application of stimulators to block each $\mathrm{K}^{+}$channel responses. To rule out nerve mediated response, sometimes nerve blockers cocktail (NBC; tetrodotoxin (TTX, $0.4 \mu \mathrm{M}$ ), guanethidine $(1 \mu \mathrm{M})$, atropine (ATR, $1 \mu \mathrm{M})$ was also used. Sometimes phentolamine (Phento, $5 \mu \mathrm{M}$ ) and proparnonol (Propra, $5 \mu \mathrm{M}$ ) was added to NBC for blocking adrenergic response too. All drugs used in this study were purchased from Sigma.

\section{Statistics}

Data were expressed as means \pm standard errors (means \pm SEM). The Student's $t$-test was used to measure the statistical significance. $p$ value less than 0.05 was regarded as statistically significant.

A

B
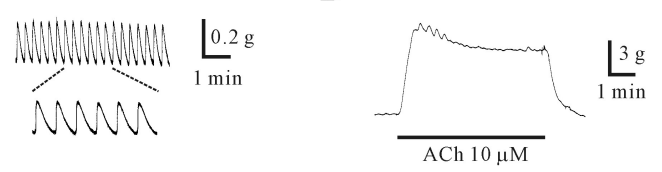

C

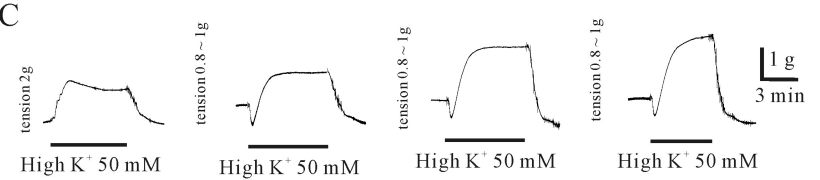

D

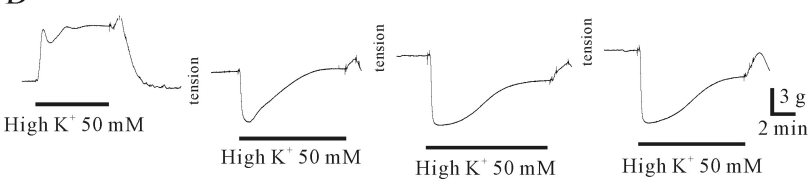

E

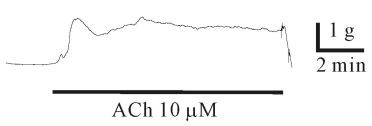

Fig. 1. Contractions of circular and longitudinal smooth muscle of the fundus greater curvature (GC). Circular muscle of the fundus GC showed spontaneous contraction (A). In (C) high- $\mathrm{K}^{+}$produced an initial and a tonic contraction and it reached peak by stepwise stretch $(0.8 \sim 1 \mathrm{~g})$. ACh $(10 \mu \mathrm{M})$ produced triphasic contractions in panel (B). Longitudinal muscle of the fundus lesser curvature (LC) obtained from a patient who underwent repetitive gastrectomy showed large high $\mathrm{K}^{+}$-induced relaxation (D). ACh produced contraction in the longitudinal muscle (E). 
Table 1. Analyzed data from circular and longitudinal smooth muscle in various regions of human stomach

\begin{tabular}{|c|c|c|c|c|c|c|}
\hline & \multirow[b]{2}{*}{$\begin{array}{l}\text { Spontaneous contraction } \\
\text { (g, cycles/min) }\end{array}$} & \multicolumn{2}{|c|}{ High $\mathrm{K}^{+}$-induced response } & \multicolumn{3}{|c|}{ Acetylcholine (ACh, $10 \mathrm{mM})$} \\
\hline & & Initial & Sustained & Initial peak & Tonic & $\begin{array}{c}\text { Phasic } \\
\text { (g, cycles/min) }\end{array}$ \\
\hline $\begin{array}{l}\text { Fundus GC } \\
\text { CircM }\end{array}$ & $\begin{array}{l}0.2 \pm 0.06 \mathrm{~g} \quad(\mathrm{n}=17) \\
4.8 \pm 0.26 \quad(\mathrm{n}=17)\end{array}$ & $5.3 \pm 1.54 \mathrm{~g}(\mathrm{n}=7)$ & $5.1 \pm 1.66 \mathrm{~g}(\mathrm{n}=13)$ & $3.7 \pm 0.97 \mathrm{~g} \quad(\mathrm{n}=14)$ & $1.1 \pm 0.25 \mathrm{~g} \quad(\mathrm{n}=14)$ & $0.7 \pm 0.22 \mathrm{~g} \quad(\mathrm{n}=12)$ \\
\hline $\begin{array}{l}\text { Fundus GC } \\
\text { LongM }\end{array}$ & $\begin{array}{rl}0.15 \pm 0.03 & \mathrm{~g}(\mathrm{n}=9) \\
3.5 \pm 0.17 & (\mathrm{n}=9)\end{array}$ & $0.5 \pm 0.09 \mathrm{~g} \quad(\mathrm{n}=14)$ & $-1.4 \pm 0.23 \mathrm{~g}(\mathrm{n}=18)$ & $1.34 \pm 0.13 \mathrm{~g} \quad(\mathrm{n}=10)$ & $1.0 \pm 0.18 \mathrm{~g} \quad(\mathrm{n}=12)$ & \\
\hline $\begin{array}{l}\text { Fundus LC } \\
\text { CircM }\end{array}$ & $\begin{array}{rl}0.03 \pm 0.01 & \mathrm{~g}(\mathrm{n}=4) \\
1.7 \pm 0.24 & (\mathrm{n}=4)\end{array}$ & $6.1 \pm 1.14 \mathrm{~g}(\mathrm{n}=4)$ & $5.0 \pm 1.28 \mathrm{~g}(\mathrm{n}=4)$ & $4.7 \pm 0.13 \mathrm{~g} \quad(\mathrm{n}=4)$ & $2.5 \pm 0.67 \mathrm{~g} \quad(\mathrm{n}=4)$ & $\begin{array}{l}0.7 \pm 0.27 \mathrm{~g} \quad(\mathrm{n}=2) \\
1.5 \pm 0.21 \quad(\mathrm{n}=2)\end{array}$ \\
\hline $\begin{array}{l}\text { Fundus LC } \\
\text { LongM }\end{array}$ & $\begin{array}{cl}\text { L: } & 1.7 \pm 0.20 \mathrm{~g} \quad(\mathrm{n}=4) \\
& 0.5 \pm 0.05 \quad(\mathrm{n}=4) \\
\text { S: } & 0.3 \pm 0.03 \mathrm{~g} \quad(\mathrm{n}=3)\end{array}$ & $4.2 \pm 0.63 \mathrm{~g} \quad(\mathrm{n}=4)$ & $0.7 \pm 0.66 \mathrm{~g} \quad(\mathrm{n}=4)$ & $6.0 \pm 1.0 \mathrm{~g}(\mathrm{n}=4)$ & $3.7 \pm 2.2 \mathrm{~g} \quad(\mathrm{n}=4)$ & $\begin{array}{l}3.2 \pm 0.9 \mathrm{~g} \quad(\mathrm{n}=4) \\
1.1 \pm 0.23 \quad(\mathrm{n}=4)\end{array}$ \\
\hline
\end{tabular}

GC, greater curvature; CircM, circular muscle; LongM, longitudinal muscle; L, large; S, small.

\section{RESULTS}

\section{Isometric contraction of circular smooth muscle in the human gastric fundus greater curvature (GC)}

Human gastric circular muscle from the fundus GC showed spontaneous contractions $(0.2 \mathrm{~g}, \mathrm{n}=17$, Fig. 1A, Table 1). However, spontaneous contractility generally disappeared, except some cases due to stepwise stretch (Fig. 1C). High $\mathrm{K}^{+}(50 \mathrm{mM})$ also produced an initial peak and sustained tonic contraction of $5.3 \mathrm{~g}$ and $5.1 \mathrm{~g}$ (Fig. 1C, Table 1). Contraction of the GC reached a peak level by applying a stepwise stretch $(0.8 \sim 1 \mathrm{~g})$ from normal length (Fig. 1C). Initial transient, phasic and sustained tonic contractions were produced by acetylcholine (ACh) $(10 \mu \mathrm{M})$ (Fig. 1B; Table 1).

\section{Isometric contraction of longitudinal smooth muscle in the human gastric fundus GC}

Isometric contractions of the longitudinal muscle in the human gastric fundus were investigated (Fig. 1D and 1E). This sample was obtained from a patient who underwent repetitive gastrectomy for a gastric cancer recurrence. In contrast to circular muscle of the fundus GC (Fig. 1C), longitudinal smooth muscles showed high $\mathrm{K}^{+}$-induced relaxation repetitively with stepwise stretches $(1.5 \sim 2 \mathrm{~g}$ ) (Fig. 1D and $1 \mathrm{E})$. However, ACh $(10 \mu \mathrm{M})$ elicited contraction in these tissues (Fig. 1E). We investigated contractile properties of longitudinal muscle to verify these discrepancies between circular and longitudinal muscle. As shown in Fig. $2 \mathrm{~A}$, isometric contraction of longitudinal muscle resulted in spontaneous rhythmic contractions of $0.15 \mathrm{~g}(\mathrm{n}=9$; Fig. 2A; Table 1), which were attenuated and nearly abolished after applying a $1 \mathrm{~g}$ load 3-5 times (Fig. $2 \mathrm{C}$ and 2D). High $\mathrm{K}^{+}$ and ACh also produced contractions (Fig. 2A and 2B; Table 1).

To test the stretch-dependency of high $\mathrm{K}^{+}$-induced relaxation, we applied increasing tension to the fundus GC longitudinal muscle strip in a stepwise fashion. As shown in Fig. $2 \mathrm{C}$, high $\mathrm{K}^{+}$-induced relaxation increased: initial contraction and subsequent relaxation $(0.5 \pm 0.09 \mathrm{~g}$ and of -1.4 $\pm 0.23 \mathrm{~g} ; \mathrm{n}=14$ and $\mathrm{n}=18$; Fig. $2 \mathrm{Ea}$ ). The response was $-61 \pm$ $9.67 \%$ of total relaxation to basal tone ( $\mathrm{n}=18$, Fig. 2Eb). High $\mathrm{K}^{+}$-induced relaxation was compared to the effect of sodium nitroprusside (SNP), a nitric oxide (NO) donor. SNP
A

B

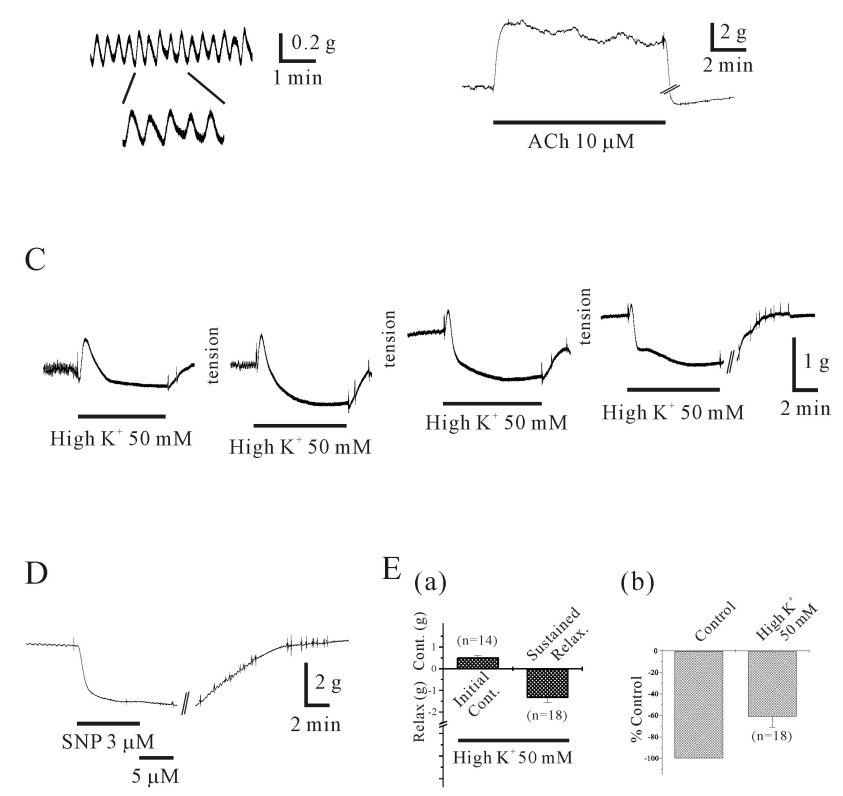

Fig. 2. High $\mathrm{K}^{+}$-induced relaxation of longitudinal smooth muscle in the fundus GC. Longitudinal muscle showed spontaneous (A) and ACh-induced contraction (B) however high $\mathrm{K}^{+}$produced relaxation (C). High $\mathrm{K}^{+}$-induced relaxation was gradually increased by application of stepwise stretch (C). In (D) SNP (3 and $5 \mu \mathrm{M})$ produced relaxation of $-3.0 \mathrm{~g}$. High $\mathrm{K}^{+}$produced relaxation $(-1.4$ g; Ea) and it was $-61 \%$ of total relaxation to basal tone (Eb).

(3 and $5 \mu \mathrm{M}$ ) produced relaxation of $-3.0 \pm 0.39 \mathrm{~g}$ and -3.0 $\pm 0.41 \mathrm{~g}$, which was equivalent to $-95 \pm 12.5 \%$ and $-99 \pm$ $13.7 \%$ from basal tone, respectively $(n=4$; Fig. 2D). Therefore, stretch-dependent relaxation $(-1.5 \pm 0.47 \mathrm{~g})$ was equivalent to $-41 \pm 14.6 \%$ of SNP $(5 \mu \mathrm{M})$-induced relaxation $(\mathrm{n}=3$, respectively).

\section{Effects of $\mathrm{K}^{+}$channel blockers on stretch-dependent relaxation of longitudinal muscle from the human gastric fundus $G C$}

Because high $\mathrm{K}^{+}$produced relaxation in longitudinal muscle, we studied whether activation of $\mathrm{K}^{+}$channels is 
associated with this stimulation using $\mathrm{K}^{+}$channel blockers. Applying tetraetylammonium (TEA, $10 \mathrm{mM}$ ), a blocker of $\mathrm{Ca}^{2+}$-activated $\mathrm{K}^{+}$channels $\left(\mathrm{K}_{\mathrm{Ca}}\right.$ channel), decreased phasic contractions $(0.03 \pm 0.02 \mathrm{~g}, \mathrm{n}=3$ from $0.06 \pm 0.02 \mathrm{~g}, \mathrm{n}=4)$, increased frequency $(4.8 \pm 0.17$ cycles $/ \mathrm{min}, \mathrm{n}=3$ from $3.4 \pm 1.12$ cycles/min, $\mathrm{n}=4)$ and produced slight tonic contractions $(0.4$ $\pm 0.13 \mathrm{~g}, \mathrm{n}=6)$. However, high $\mathrm{K}^{+}$-induced relaxation $(-0.8$ $\pm 0.15 \mathrm{~g}, \mathrm{n}=6)$ was not inhibited but rather potentiated $(-1.4$ $\pm 0.23 \mathrm{~g}, \mathrm{n}=6)$ by TEA pre-treatment (Fig. 3A), as TEA (10 $\mathrm{mM})$ produced tonic contractions $(0.4 \mathrm{~g})$. High $\mathrm{K}^{+}$-induced relaxation was also investigated in the presence of a $\mathrm{K}^{+}$ channel blocker cocktail (KBC, except 4-AP, see Methods). As shown in Fig. $3 \mathrm{~B}$ and $3 \mathrm{Ca}$, the $\mathrm{KBC}$ produced a tonic contraction of $0.6 \pm 0.24 \mathrm{~g}(\mathrm{n}=6)$, and high $\mathrm{K}^{+}$-induced relaxation in the presence of the KBC was $-1.2 \pm 0.28 \mathrm{~g}(\mathrm{n}=6$; $\mathrm{p}<0.05)$. The percent relaxation of high $\mathrm{K}^{+}$-induced relaxation with the $\mathrm{KBC}$ was comparable with $-92 \pm 33.4 \%$ from the initial basal tension level $(n=6$, Fig. $3 \mathrm{Cb})$.

Effects of protein kinase (PK) inhibitors on high $\mathrm{K}^{+}$induced relaxation of longitudinal smooth muscle in the human gastric fundus GC

The involvement of activated PKG and PKA on high $\mathrm{K}^{+}$. induced relaxation was evaluated. As shown in Fig. 3D, high $\mathrm{K}^{+}$-induced relaxation was produced in longitudinal

A
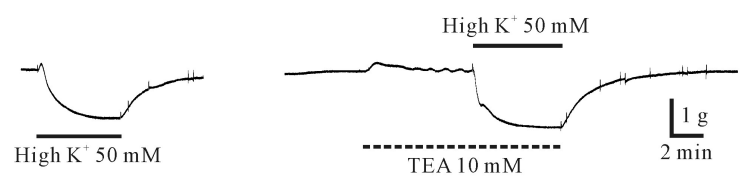

B
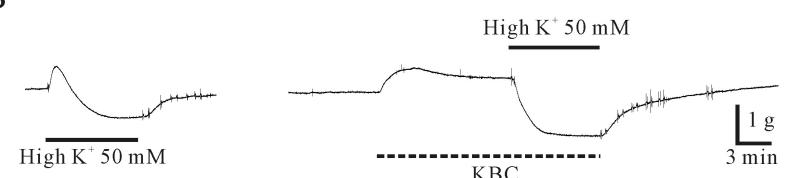

C

(a)

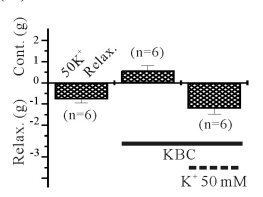

$\mathrm{D}$

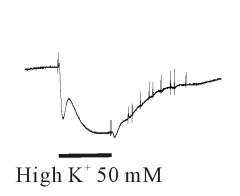

High $\mathrm{K}^{+} 50 \mathrm{mM}$

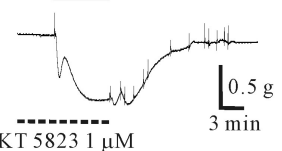

Fig. 3. Effect of inhibitors of $\mathrm{K}^{+}$channels and protein kinases (PK) on high $\mathrm{K}^{+}$-induced relaxation of longitudinal smooth muscle in the fundus GC. High $\mathrm{K}^{+}$-induced relaxation was not inhibited by tetraethylammonium (TEA, $10 \mathrm{mM}$ ) which is known inhibitor of $\mathrm{Ca}^{2+}$-activated $\mathrm{K}^{+}$channel $\left(\mathrm{K}_{\mathrm{Ca}}\right.$ channel) (A) and also not by $\mathrm{K}^{+}$ channel blockers cocktail (KBC except 4-AP, see methods; (B), (Ca, $\mathrm{Cb}$ ). Furthermore, it was not affected by KT5823 and KT5720, blockers of PKG and PKA, respectively (D, E). smooth muscle of the human fundus GC. High $\mathrm{K}^{+}$-induced relaxation was not inhibited by KT $5823(1 \mu \mathrm{M})$ or KT 5720 $(1 \mu \mathrm{M})$, blockers of PKG and PKA, respectively. High $\mathrm{K}^{+}$. induced relaxation was $-1.8 \pm 0.81 \mathrm{~g}$ and $-2.0 \pm 0.81 \mathrm{~g}$ in the absence and presence of KT $5823(1 \mu \mathrm{M}, \mathrm{n}=4)$, and was $-1.5 \pm 0.57 \mathrm{~g}$ and $-1.3 \pm 0.59 \mathrm{~g}$ in the absence and presence of KT $5720(1 \mu \mathrm{M}, \mathrm{n}=5)$, respectively ( $>0.05$; Fig. $3 \mathrm{D}$ and $3 \mathrm{E})$. KT $5823(1 \mu \mathrm{M})$ and KT $5720(1 \mu \mathrm{M})$ weakly inhibited basal tone $(-0.03$ to $-0.053 \mathrm{~g} ; \mathrm{n}=4$ and 5 ; data not shown). Thus, the percent relaxation of high $\mathrm{K}^{+}$ -induced relaxation was calculated as $-131.1 \pm 31.2 \%$ and $-102.3 \pm 3.7 \%$ in the presence of KT 5823 and KT 5720 , respectively ( $\mathrm{n}=4$ and $5, \mathrm{p}>0.05)$.

\section{Effects of NO inhibitors and soluble guanylyl cyclase (sGC) on high $\mathrm{K}^{+}$-induced relaxation of longitudinal smooth muscle in the human gastric fundus GC}

The involvement of NO and sGC on high $\mathrm{K}^{+}$-induced relaxation was investigated. High $\mathrm{K}^{+}$-induced relaxation was significantly antagonized and reversed to contraction by NG-nitro-L-arginine (L-NNA), an NO biosynthesis inhibitor. As shown in Fig. 4A, high $\mathrm{K}^{+}$-induced relaxation was $-1.4 \pm 0.34 \mathrm{~g}$ in the absence of L-NNA $(\mathrm{n}=14)$. However, high $\mathrm{K}^{+}$produced initial peak contraction $(1.4 \pm 0.34 \mathrm{~g}$, $\mathrm{n}=13)$ and sustained tonic contraction $(1.01 \pm 0.29 \mathrm{~g}, \mathrm{n}=14)$ after L-NNA treatment $(100 \mu \mathrm{M})$, which slightly increased basal tone to $0.02 \pm 0.13 \mathrm{~g}(\mathrm{n}=14)$ (Fig. $4 \mathrm{~A}$ and $4 \mathrm{C})$. The effect

A
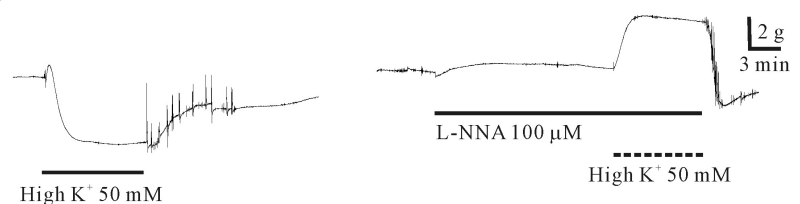

B
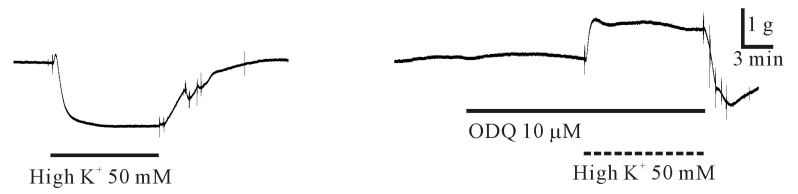

$\mathrm{C}$

$\mathrm{D}$
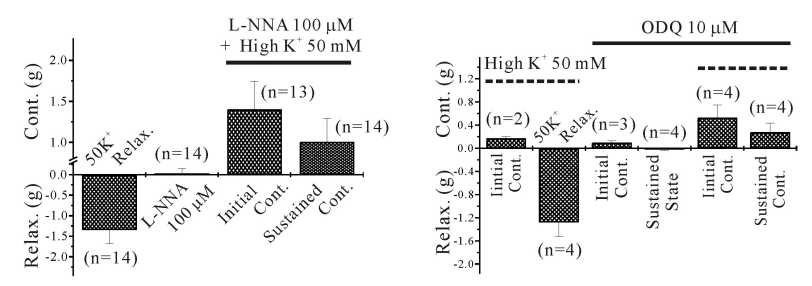

Fig. 4. Involvement of nitric oxide (NO) and soluble guanylyl cyclase (sGC) on high $\mathrm{K}^{+}$-induced relaxation of longitudinal smooth muscle in the fundus GC. In (A, B) high $\mathrm{K}^{+}$produced relaxation in longitudinal muscle in the fundus GC. However, L-NNA (100 $\mu \mathrm{M})$ and ODQ $(10 \mu \mathrm{M})$ blocked and reversed high $\mathrm{K}^{+}$-induced relaxation to contraction $(\mathrm{A}, \mathrm{B})$. The data were summarized in $(\mathrm{C}$, D). 
of ODQ, an sGC inhibitor, on high $\mathrm{K}^{+}$-induced relaxation was also studied. Applying ODQ $(10 \mu \mathrm{M})$ produced an initial contraction $(0.1 \pm 0.04 \mathrm{~g})$ and a slowly decaying contraction to $-0.02 \pm 0.02 \mathrm{~g}$, respectively $(\mathrm{n}=3$ and 4 respectively). In the absence of ODQ, high $\mathrm{K}^{+}$-induced relaxation $(-1.3 \pm 0.3 \mathrm{~g}, \mathrm{n}=4)$ was reversed to initial and sustained contractions of $0.5 \pm 0.22 \mathrm{~g}$ and $0.3 \pm 0.16 \mathrm{~g}$ ( $\mathrm{n}=4$, respectively; Fig. $4 \mathrm{~B}$ and $4 \mathrm{D})$.

Effects of 4-aminopyridine (4-AP) on high $\mathrm{K}^{+}$-induced relaxation of longitudinal smooth muscle in the human gastric fundus $G C$

The involvement of $\mathrm{K}_{\mathrm{V}}$ channels on high $\mathrm{K}^{+}$-induced relaxation was also investigated, using 4-AP and a nerve blocker cocktail (NBC, see methods). As shown in Fig. 5B, high $\mathrm{K}^{+}$-induced relaxation was $-2.2 \pm 0.59 \mathrm{~g}$ in the absence of 4-AP $(\mathrm{n}=4)$. 4-AP $(5 \mathrm{mM})$ produced initial contractions, transient, and sustained relaxation of $0.8 \pm 0.45 \mathrm{~g},-1.3 \pm$ $0.86 \mathrm{~g}$, and $-0.6 \pm 0.49 \mathrm{~g}$ ( $\mathrm{n}=4,3$ and 3 , respectively). However, high $\mathrm{K}^{+}$-induced relaxation was reversed in the presence of 4-AP to initial $(1.0 \pm 0.48 \mathrm{~g}, \mathrm{n}=4)$ and following sustained contraction $(0.1 \pm 0.15 \mathrm{~g}, \mathrm{n}=4)(\mathrm{p}<0.05)$.

NBC itself did not show any significant effect on basal contractility. High $\mathrm{K}^{+}$-induced relaxation in the absence and presence of the NBC was $-2.6 \pm 0.33 \mathrm{~g}$ and $-2.8 \pm 0.53$ $g$, respectively $(n=6$, respectively; $p>0.05)$. To study the

A

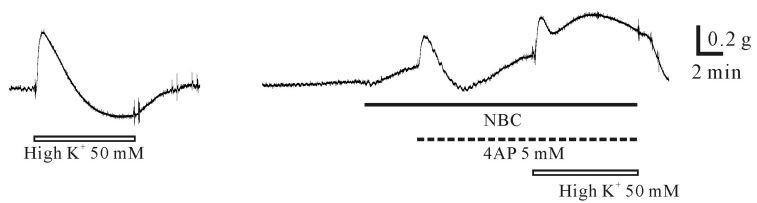

B

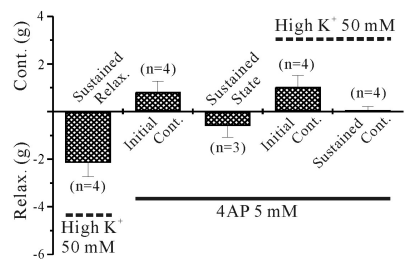

C

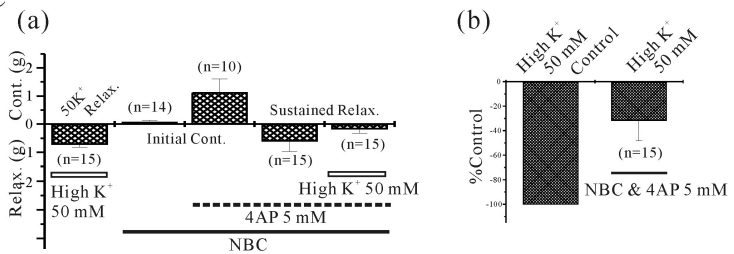

Fig. 5. Effects of 4-aminopyridine (4-AP) on high $\mathrm{K}^{+}$-induced relaxation of longitudinal smooth muscle in the fundus GC. Most high $\mathrm{K}^{+}$-induced relaxation were blocked or reversed to contraction (A), though some were not, by pretreatment of 4-AP with nerve blockers cocktail (NBC, see methods; C). In (B) effect of 4-AP (5 $\mathrm{mM}$ ) on high $\mathrm{K}^{+}$-induced relaxation was summarized. In the presence of 4-AP $(5 \mathrm{mM})$, high $\mathrm{K}^{+}$-induced relaxation was inhibited. In the presence of $\mathrm{NBC}$ and 4-AP, the percent relaxation of high $\mathrm{K}^{+}$-induced relaxation was suppressed (Ca) to $-32 \%$ of the control $(\mathrm{Cb})$.

possible involvement of neurotransmitters in the 4-AP effect, we also studied the effect of 4-AP in the presence of the NBC, as a neurotransmitter releasing effect by 4-AP, a $\mathrm{K}_{\mathrm{V}}$ channel blocker, has been reported. As shown in Fig. $5 \mathrm{C}$, high $\mathrm{K}^{+}$-induced relaxation in the control was $-0.7 \pm 0.1$ $\mathrm{g}(\mathrm{n}=15)$. Applying the NBC slightly increased basal tone by $0.1 \pm 0.04 \mathrm{~g}(\mathrm{n}=14)$ and adding 4 -AP produced an initial contraction of $1.1 \pm 0.48 \mathrm{~g}(\mathrm{n}=10)$, followed by relaxation of $-0.6 \pm 0.35 \mathrm{~g}(\mathrm{n}=15)$. Most high $\mathrm{K}^{+}$-induced relaxation was inhibited or reversed to contraction in the presence of $\mathrm{NBC}$ and 4-AP, although some were not (Fig. 5A). Therefore, high $\mathrm{K}^{+}$-induced relaxation in the presence of 4-AP and the NBC significantly attenuated the value to $-0.18 \pm 0.14 \mathrm{~g}$ $(\mathrm{n}=15)$ compared to that of high $\mathrm{K}^{+}$-induced relaxation without 4-AP $(-0.7 \pm 0.1 \mathrm{~g}, \mathrm{n}=15)(\mathrm{p}<0.05$; Fig. 5Ca). The percent relaxation of high $\mathrm{K}^{+}$-induced relaxation in the presence of the NBC with 4 -AP was $-32 \pm 16.2 \%$ from the initial basal tension level $(\mathrm{n}=15)$ (Fig. $5 \mathrm{Cb})$.

\section{Response of circular and longitudinal smooth muscle of the human stomach fundus lesser curvature (LC) to high $K^{+}$}

Circular smooth muscle from the fundus LC showed phasic contractions of $0.03 \mathrm{~g}$. However, longitudinal muscle of the fundus LC showed large phasic contractions of $1.7 \mathrm{~g}$, and small phasic contractions of $0.3 \mathrm{~g}$ were superimposed on top of these large contractions $(n=4$ and 3; Table 1). High $\mathrm{K}^{+}$produced initial and tonic contractions of $6.1 \pm 1.14 \mathrm{~g}$ and $5.0 \pm 1.28 \mathrm{~g}$ in circular muscle $(\mathrm{n}=4$, respectively; Fig. $6 \mathrm{~A})$. Longitudinal muscle also produced an initial contraction of $4.2 \pm 0.63 \mathrm{~g}$ followed by a tonic contraction of $0.7 \pm 0.66 \mathrm{~g}$ due to high $\mathrm{K}^{+}$(n=4, Fig. 6B).

\section{DISCUSSION}

The stomach elicits various motor activities to perform its physiological functions such as acting as a reservoir and grinding and so on $[14,15]$. Among them, receptive relaxation is the best characterized function of the proximal stomach. Gastric relaxation of the fundus is key to accommodate ingested material with a minimal increase in intraluminal pressure. To date, gastric accommodation has been explained by various mechanisms. One of them is receptive relaxation known as the vago-vagal reflex [5]. The second mechanism is called adaptive relaxation by the short vagal

A

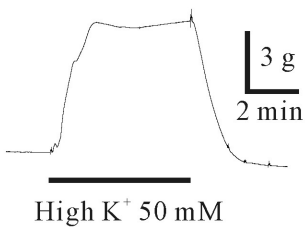

Fig. 6. High $\mathrm{K}^{+}$-induced response in the fundus LC. Contractile properties of circular and longitudinal smooth muscles of the fundus LC were investigated too. Circular muscle of the fundus LC showed high $\mathrm{K}^{+}$-induced contraction (A). Meanwhile, high $\mathrm{K}^{+}$ produced an initial contraction followed by an weak contraction in longitudinal muscle of the fundus LC (B). 
reflex. In particular, NO is a principal candidate for fundus relaxation [16]. We recently discovered NO-dependent relaxation in the corpus [13]. We also found that L-NNA inhibited high $\mathrm{K}^{+}$-induced relaxation in longitudinal smooth muscle of the fundus GC, as shown in Figs. 2C, 2E and $3 \sim 5$. Furthermore, ODQ blocked high $\mathrm{K}^{+}$-induced relaxation and reversed relaxation to contraction (Fig. $4 \mathrm{~B}$ and 4D).

We also investigated the involvement of PKG on high $\mathrm{K}^{+}$. induced relaxation, as NO is known to activate guanylate cyclase (Fig. 3D and 3E). However, the PKG inhibitor KT5823 and the PKA inhibitor KT5720 (and S22536, not shown) did not affect this relaxation effect. Thus, we suggest that NO/cGMP-mediated the high $\mathrm{K}^{+}$-induced relaxation of longitudinal muscle in the human proximal stomach. Direct NO/cGMP-dependent and PKG-independent pathways for regulation of $\mathrm{K}$ channels are also present [17]. Interestingly, high $\mathrm{K}^{+}$-induced contraction of some circular muscle was followed by small transient relaxation, which was blocked by L-NNA (Fig. 1C). This observation suggests that NO mediated relaxing mechanisms are also present in circular muscle to a lesser degree.

NO is localized in myenteric neurons of the human gastric fundus and mediates relaxation of the fundus [10]. Relaxation by graded mechanical distention has been partly ascribed to a NO-mediated neurogenic component. Although it remains controversial, NO is believed to mediate gastric accommodation in the human stomach [10]. Because high $\mathrm{K}^{+}$-induced relaxation in human fundus longitudinal muscle was completely inhibited by L-NNA and converted to contraction (Fig. $4 \mathrm{~A}$ and $4 \mathrm{C}$ ), we believe that $\mathrm{NO}$ is a mediator for high $\mathrm{K}^{+}$-induced relaxation [18].

Several layers of muscle are found in the human stomach $[19,20]$. Circular and longitudinal muscle is regulated by the coordination of slow waves [21]. In this study, we found a functional dissociation between these muscles in the human stomach. Stimulation with high $\mathrm{K}^{+}$concentrations resulted in contraction of circular muscles but relaxation of longitudinal muscles. The mechanism underlying the responses of each muscle layer seems very complicated, indicating different regulation of intracellular $\mathrm{Ca}^{2+}\left(\left[\mathrm{Ca}^{2+}\right]_{i}\right)$ by $\mathrm{K}^{+}$-stimulation and/or regional differences in electrical characteristics of each type of gastric muscle [12,22,23]. Dissociation of motility between both muscles might come from different characteristics of the muscles and/or neural responses [12].

The relaxation phenomenon of the human gastric fundus after gastrectomy is clinically interesting. We found that this relaxation was highly enhanced in a patient who underwent repetitive gastrectomy (Fig. 1D and 1E). A direct complication of gastrectomy is loss of gastric reservoir function. However, gastric volume after a subtotal gastrectomy is partly recovered by proper alimentotherapy. As a subtotal gastrectomy saves the gastric proximal region, its relaxation seems very natural. Further study is required to understand this phenomenon.

All visceral smooth muscles require $\mathrm{Ca}^{2+}$ for contraction, and the amplitude of the contraction depends on $\left[\mathrm{Ca}^{2+}\right]_{\mathrm{i}}$ [24]. To date, $\operatorname{VDCC}_{L}$ have been described in most excitable tissues, including the human stomach [25], and $\mathrm{VDCC}_{\mathrm{L}}$ play an essential role in the regulation of $\left[\mathrm{Ca}^{2+}\right]_{\mathrm{i}}[11]$. Spontaneous contractility of GI muscles is closely related to slow waves, and activation of $\mathrm{VDCC}_{\mathrm{L}}$ on the slow wave plateau is necessary for excitation-contraction (E-C) coupling [26]. In general, phasic contraction of the GI tract produces peristaltic contractions [28]. Therefore, an investigation of $\mathrm{Ca}^{2+}$ current regulation is essential to understand gastric functions [27]. We studied the effect of high $\mathrm{K}^{+}$-induced contraction in the human stomach (Fig. 1C). High $\mathrm{K}^{+}$generally produces contractions via activation of $\mathrm{VDCC}_{\mathrm{L}}$ in gastric smooth muscle [12]. However, we found relaxation due to high $\mathrm{K}^{+}$stimulation in longitudinal muscle of the fundus from the GC. Relaxation of longitudinal smooth muscle in contrast to circular muscle occurs due to various reasons such as different spontaneous electrical activity in each muscle [23], dissociation of motility and regulation of $\left[\mathrm{Ca}^{2+}\right]_{\mathrm{i}}$, including the different properties of the muscle fibers [12]. Differences in the cytoskeleton and/or some unknown regulatory mechanism related to mechanical stress might underlie this relaxation response $[28,29]$. These results suggest that longitudinal muscle might also have special directionality of its own like circular muscle.

As shown in Figs. 4A, 4C, and 5, high $\mathrm{K}^{+}$-induced relaxation of longitudinal muscle was transited to contraction by 4-AP and ODQ but not by KT5823 and KT5720 (Fig. 3D and $3 \mathrm{E}$ ). These findings suggest that the NO/sGC pathway is selectively involved (Fig. $3 \mathrm{D}$ and $3 \mathrm{E}$ ). In fact, $\mathrm{K}^{+}$channels such as the $\mathrm{K}_{\mathrm{V}}$ channel $[17,30]$ and $\mathrm{K}_{\mathrm{Ca}}$ channel [31] are directly regulated by the NO/sGC pathway in smooth muscle [13]. In addition, nNOS neurons are found in the myenteric region of the human stomach [32]. Interstitial cells of Cajal (ICC) express NO-sensitive sGC and are a primary target of NO released from nNOS neurons; thus, NO signals are transmitted to smooth muscle in the GI tract $[33,34]$. From these observations, we suggest that high $\mathrm{K}^{+}$-induced relaxation is produced by activating $\mathrm{VDCC}_{\mathrm{L}}$ and by the NO/sGC-dependent pathway of the ICC in the longitudinal muscle layer.

NOS neurons are found in circular and longitudinal muscle layers, including the myenteric border of the GI tract [32]. However, we found that NO produced relaxation only in longitudinal smooth muscle of the human gastric greater curvature. Unfortunately, we could not clarify exactly where the NO originated. Although we used a NBC to block the nerve effect when applying high $\mathrm{K}^{+}$stimulation, there still remained a possibility of $\mathrm{NO}$ release via activation of $\mathrm{Ca}^{2+}$ channels in the NANC nerve. Therefore, the NANC nerve or other NO releasing cells could be involved in this relaxation response. In addition to an NO source, the reason why only longitudinal muscles respond with relaxation to high $\mathrm{K}^{+}$stimulation in the greater curvature side and why an enhanced response occurs in patients with recurrent gastric cancer must be investigated.

\section{ACKNOWLEDGEMENTS}

This work was supported by the research grant of the Chungbuk National University in 2011.

\section{REFERENCE}

1. Cannon WB, Lieb CW. The receptive relaxation of the stomach. Am J Physiol. 1911;29:267-273.

2. Paton WD, Vane JR. Analysis of the responses of the isolated stomach to electrical stimulation and to drugs. J Physiol. 1963;165:10-46.

3. Hennig GW, Brookes SJ, Costa M. Excitatory and inhibitory motor reflexes in the isolated guinea-pig stomach. J Physiol. 1997;501:197-212. 
4. Desai KM, Sessa WC, Vane JR. Involvement of nitric oxide in the reflex relaxation of the stomach to accommodate food or fluid. Nature. 1991;351:477-479.

5. Abrahamsson H. Studies on the inhibitory nervous control of gastric motility. Acta Physiol Scand Suppl. 1973;390:1-38.

6. Barbier AJ, Lefebvre RA. Involvement of the L-arginine: nitric oxide pathway in nonadrenergic noncholinergic relaxation of the cat gastric fundus. J Pharmacol Exp Ther. 1993;266: $172-178$.

7. Lefebvre RA, Smits GJ, Timmermans JP. Study of NO and VIP as non-adrenergic non-cholinergic neurotransmitters in the pig gastric fundus. $\mathrm{Br} J$ Pharmacol. 1995;116:2017-2026.

8. Meulemans AL, Helsen LF, Schuurkes JA. Role of NO in vagally-mediated relaxations of guinea-pig stomach. Naunyn Schmiedebergs Arch Pharmacol. 1993;347:225-230.

9. Yano S, Kiyota Y, Yamamoto M, Watanabe K. Pharmacological features of non-adrenergic non-cholinergic (NANC) relaxation induced by electrical vagal stimulation in isolated mouse stomach. Jpn J Pharmacol. 1995;69:9-15.

10. Tonini M, De Giorgio R, De Ponti F, Sternini C, Spelta V, Dionigi P, Barbara G, Stanghellini V, Corinaldesi R. Role of nitric oxide- and vasoactive intestinal polypeptide-containing neurones in human gastric fundus strip relaxations. $\mathrm{Br} J$ Pharmacol. 2000;129:12-20.

11. Kim SJ, Ahn SC, Kim JK, Kim YC, So I, Kim KW. Changes in intracellular $\mathrm{Ca}^{2+}$ concentration induced by L-type $\mathrm{Ca}^{2+}$ channel current in guinea pig gastric myocytes. Am J Physiol. 1997;273:C1947-1956.

12. Kuriyama H, Mishima K, Suzuki H. Some differences in contractile responses of isolated longitudinal and circular muscle from the guinea-pig stomach. J Physiol. 1975;251: 317-331.

13. Kim YC, Choi W, Yun HY, Sung R, Yoo RY, Park SM, Yun SJ, Kim MJ, Song YJ, Xu WX, Lee SJ. Nitric oxide-mediated relaxation by high $\mathrm{K}$ in human gastric longitudinal smooth muscle. Korean J Physiol Pharmacol. 2011;15:405-413.

14. Schubert ML, Makhlouf GM. Gastrin secretion induced by distention is mediated by gastric cholinergic and vasoactive intestinal peptide neurons in rats. Gastroenterology. 1993;104: 834-839.

15. Shafik A, El Sibai O, Shafik AA, Shafik IA. Mechanism of gastric emptying through the pyloric sphincter: a human study. Med Sci Monit. 2007;13:CR24-29.

16. Burnstock G. The non-adrenergic non-cholinergic nervous system. Arch Int Pharmacodyn Ther. 1986;280(2 Suppl):1-15.

17. Derici K, Samsar U, Demirel-Yilmaz E. Nitric oxide effects depend on different mechanisms in different regions of the rat heart. Heart Vessels. 2012;27:89-97.

18. Dixit D, Zarate N, Liu LW, Boreham DR, Huizinga JD. Interstitial cells of Cajal and adaptive relaxation in the mouse stomach. Am J Physiol Gastrointest Liver Physiol. 2006;291: G1129-1136.

19. Sung R, Kim YC, Yun HY, Choi W, Kim HS, Kim H, Lee KJ, You RY, Park SM, Youn SJ, Kim MJ, Kim WS, Song YJ, Kim SY, Xu WX, Lee SJ. Interstitial cells of Cajal (ICC)-like-c-Kit positive cells are involved in gastritis and carcinogenesis in human stomach. Oncol Rep. 2011;26:33-42.

20. Yun HY, Sung R, Kim YC, Choi W, Kim HS, Kim H, Lee GJ, You RY, Park SM, Yun SJ, Kim MJ, Kim WS, Song YJ, Xu WX, Lee SJ. Regional distribution of interstitial cells of Cajal (ICC) in Human Stomach. Korean J Physiol Pharmacol. 2010;14:317-324.

21. Cousins HM, Edwards FR, Hickey H, Hill CE, Hirst GD. Electrical coupling between the myenteric interstitial cells of Cajal and adjacent muscle layers in the guinea-pig gastric antrum. J Physiol. 2003;550:829-844.

22. Osa T, Kuriyama H. The membrane properties and decremental conduction of excitation in the fundus of the guinea-pig stomach. Jpn J Physiol. 1970;20:626-639.

23. Connor C, Prosser CL. Comparison of ionic effects on longitudinal and circular muscle of cat jejunum. Am J Physiol. 1974; 226:1212-1218.

24. Somlyo AP, Somlyo AV. Signal transduction and regulation in smooth muscle. Nature. 1994;372:231-236.

25. Hagiwara S, Byerly L. Membrane biophysics of calcium currents. Fed Proc. 1981;40:2220-2225.

26. Barajas-López C, Huizinga JD. Different mechanisms of contraction generation in circular muscle of canine colon. Am J Physiol. 1989;256:G570-580.

27. Kelly KA, Code CF. Canine gastric pacemaker. Am J Physiol. 1971;220:112-118.

28. Xu WX, Kim SJ, So I, Kim KW. Role of actin microfilament in osmotic stretch-induced increase of voltage-operated calcium channel current in guinea-pig gastric myocytes. Pflugers Arch. 1997;434:502-504.

29. Xu WX, Li Y, Wu LR, Li ZL. Effects of different kinds of stretch on voltage-dependent calcium current in antrial circular smooth muscle cells of the guinea-pig. Sheng $L i$ Xue Bao. 2000;52:69-74.

30. Yuan XJ, Tod ML, Rubin LJ, Blaustein MP. NO hyperpolarizes pulmonary artery smooth muscle cells and decreases the intracellular $\mathrm{Ca}^{2+}$ concentration by activating voltage-gated $\mathrm{K}^{+}$ channels. Proc Natl Acad Sci USA. 1996;93:10489-10494.

31. Yu YC, Guo HS, Li Y, Piao L, Li L, Li ZL, Xu WX. Role of calcium mobilization in sodium nitroprusside-induced increase of calcium-activated potassium currents in gastric antral circular myocytes of guinea pig. Acta Pharmacol Sin. 2003; 24:819-825.

32. Ibba Manneschi L, Pacini S, Corsani L, Bechi P, FaussonePellegrini MS. Interstitital cells of Cajal in the human stomach: distribution and relationship with enteric innervation. Histol Histopathol. 2004;19:1153-1164.

33. Iino S, Horiguchi K, Nojyo Y. Interstitial cells of Cajal are innervated by nitrergic nerves and express nitric oxidesensitive guanylate cyclase in the guinea-pig gastrointestinal tract. Neuroscience. 2008;152:437-448.

34. Nemeth L, Puri P. Three-dimensional morphology of c-Kitpositive cellular network and nitrergic innervation in the human gut. Arch Pathol Lab Med. 2001;125:899-904. 